\title{
Plasma phyto-oestrogens and prostate cancer in the European Prospective Investigation into Cancer and Nutrition
}

\author{
RC Travis", , EA Spencer', NE Allen', PN Appleby', AW Roddam', K Overvad², NF Johnsen ${ }^{3}$, A Olsen $^{3}$, \\ R Kaaks ${ }^{4}$, J Linseisen ${ }^{4}$, H Boeing ${ }^{5}$, U Nöthlings ${ }^{5}$, HB Bueno-de-Mesquita ${ }^{6}$, MM Ros $^{6}$, C Sacerdote $^{7}$, D Palli ${ }^{8}$, \\ R Tumino', F Berrino ${ }^{10}$, A Trichopoulou ' , V Dilis' ', D Trichopoulos ${ }^{12,13}$, M-D Chirlaque ${ }^{14}$, E Ardanaz ${ }^{15,16}$, \\ N Larranaga ${ }^{17}$, C Gonzalez ${ }^{18}$, LR Suárez ${ }^{19}$, M-J Sánchez ${ }^{16,20}$, S Bingham ${ }^{21}$, K-T Khaw ${ }^{22}$, G Hallmans ${ }^{23}$, \\ P Stattin ${ }^{24}$, S Rinaldi ${ }^{25}$, N Slimani ${ }^{25}$, M Jenab ${ }^{25}$, E Riboli ${ }^{26}$ and TJ Key
}

'Cancer Epidemiology Unit, Nuffield Department of Clinical Medicine, University of Oxford, Oxford OX3 7LF, UK; '2Department of Clinical Epidemiology, Aarhus University Hospital, Aalborg, Denmark; ${ }^{3}$ Institute of Cancer Epidemiology, Danish Cancer Society, Copenhagen, Denmark; ${ }^{4}$ Division of Cancer Epidemiology, German Cancer Research Centre, Heidelberg, Germany; ${ }^{5}$ German Institute of Human Nutrition, Potsdam-Rehbruecke, Nuthetal, Germany; ${ }^{6}$ National Institute for Public Health and the Environment (RIVM), Bilthoven, The Netherlands; ${ }^{7}$ CPO-Piedmonte and ISI Foundation, Torino, Italy; ${ }^{8}$ Molecular and Nutritional Epidemiology Unit, CSPO-Scientific Institute of Tuscany, Florence, Italy; ${ }^{9}$ Cancer Registry Azienda Ospedaliera Civile-M.P. Arezzo, Ragusa, Italy; ${ }^{10}$ Department of Preventive and Predictive Medicine, Fondazione IRCCS Istituto Nazionale dei Tumori, Milan, Italy; "'Department of Hygiene and Epidemiology, University of Athens Medical School, Athens, Greece; ${ }^{12}$ Department of Epidemiology, Harvard School of Public Health, Boston, Massachusetts, USA; ${ }^{13}$ Hellenic Health Foundation, Athens, Greece; ${ }^{14}$ Epidemiology Department, Murcia Health Council, CIBER en Epidemiología y Salud, Pública (CIBERESP), Murcia, Spain; ${ }^{15}$ Public Health Institute of Navarra, Pamplona, Spain; ${ }^{16}$ CIBER Epidemiología y Salud Pública (CIBERESP), Spain; ${ }^{17}$ Public Health Department of Gipuzkoa, Basque Government, Donostia-San Sebastian, Spain; ${ }^{18}$ Unit of Nutrition, Environment and Cancer, Catalan Institute of Oncology, Barcelona, Spain; ${ }^{19}$ Public Health Directorate, Population Health Service, Health Information Section, Asturias, Spain; ${ }^{20}$ Andalusian School of Public Health, Granada, Spain; ${ }^{21}$ Department of Public Health and Primary Care, MRC Centre for Nutritional Epidemiology in Cancer Prevention and Survival, University of Cambridge, Cambridge, UK; ${ }^{22}$ Department of Public Health and Primary Care, University of Cambridge, Cambridge, UK; ${ }^{23}$ Department of Public Health and Clinical Medicine, Nutritional Research, Umeå University, Umeå, Sweden; ${ }^{24}$ Department of Surgical and Perioperative Sciences, Urology and Andrology, Umea University, Umeå, Sweden; ${ }^{25}$ International Agency for Research on Cancer, The World Health Organisation, Lyon, France; ${ }^{26}$ Department of Epidemiology and Public Health, Imperial College, London, UK

We examined plasma concentrations of phyto-oestrogens in relation to risk for subsequent prostate cancer in a case-control study nested in the European Prospective Investigation into Cancer and Nutrition. Concentrations of isoflavones genistein, daidzein and equol, and that of lignans enterolactone and enterodiol, were measured in plasma samples for 950 prostate cancer cases and I042 matched control participants. Relative risks (RRs) for prostate cancer in relation to plasma concentrations of these phyto-oestrogens were estimated by conditional logistic regression. Higher plasma concentrations of genistein were associated with lower risk of prostate cancer: RR among men in the highest vs the lowest fifth, $0.7 \mathrm{I}(95 \%$ confidence interval $(\mathrm{Cl}) 0.53-0.96, P$ trend $=0.03)$. After adjustment for potential confounders this RR was $0.74(95 \% \mathrm{Cl} 0.54-1.00, P$ trend $=0.05)$. No statistically significant associations were observed for circulating concentrations of daidzein, equol, enterolactone or enterodiol in relation to overall risk for prostate cancer. There was no evidence of heterogeneity in these results by age at blood collection or country of recruitment, nor by cancer stage or grade. These results suggest that higher concentrations of circulating genistein may reduce the risk of prostate cancer but do not support an association with plasma lignans.

British Journal of Cancer (2009) I 00, I817-1823. doi: |0.1038/sj.bjc.6605073 www.bjcancer.com

Published online 12 May 2009

(c) 2009 Cancer Research UK

Keywords: prospective; prostate cancer; plasma; isoflavone; lignan; genistein

International comparisons, small randomised trials and experimental data from animal models and cell lines suggest a possible protective association between dietary phyto-oestrogens, including isoflavones and lignans, and the development of prostate cancer (Goetzel et al, 2007; Perabo et al, 2008). Results from prospective epidemiological studies of dietary phyto-oestrogen intake and prostate cancer risk generally support this hypothesis (Severson

*Correspondence: Dr RC Travis; E-mail: ruth.travis@ceu.ox.ac.uk Received 28 January 2009; accepted 9 April 2009; published online 12 May 2009 et al, 1989; Jacobsen et al, 1998; Allen et al, 2004; Nomura et al, 2004; Low et al, 2006; Kurahashi et al, 2007), previous studies of circulating concentrations of lignans have been inconclusive (Stattin et al, 2002, 2004; Kilkkinen et al, 2003; Ward et al, 2008), and there have been no large-scale prospective investigations of circulating concentrations of isoflavones in relation to prostate cancer risk.

Here, we report the findings from the first large prospective study of plasma concentrations of isoflavones in relation to risk for prostate cancer, presenting data on prediagnostic plasma concentrations of genistein, daidzein and equol among 950 men with 
incident prostate cancer and 1042 matched control participants participating in the European Prospective Investigation into Cancer and Nutrition (EPIC). We also examine associations with plasma concentrations of the lignans enterolactone and enterodiol, and evaluate the associations of isoflavones and lignans with risk subdivided by the stage of disease and other factors.

\section{MATERIALS AND METHODS}

\section{Participants and data}

Between 1992 and 2000, 500000 individuals (150 000 men) were recruited into EPIC from 23 centres in 10 European countries. The methods of recruitment and study design have been described in detail elsewhere (Riboli et al, 2002). The participants completed an extensive questionnaire on dietary and non-dietary factors at recruitment, and about 400000 individuals (of whom 137000 were men) also provided a blood sample. All participants gave written consent for the research, and approval for the study was obtained from the Internal Review Board of the International Agency for Research on Cancer (Lyon, France) and from the local ethics committees in the participating countries.

This study includes prostate cancer cases occurring after blood collection and individually matched male control participants from the eight participating countries, which recruited men: Denmark, Germany, Greece, Italy, the Netherlands, Spain, Sweden and the United Kingdom.

Follow-up for diagnosis of prostate cancer is provided through record linkage with population-based cancer registries in six of the participating countries: Denmark, Italy, the Netherlands, Spain, Sweden and the United Kingdom. In Germany and Greece, followup is active and is achieved through checks of insurance records and cancer and pathology registries, as well as through self-reported questionnaires; self-reported incident cancers are verified through medical records. Data on vital status in most EPIC study centres were collected from mortality registries at the regional or national level, in combination with data collected by active follow-up (Greece). The 10th Revision of the International Statistical Classification of Diseases, Injuries and Causes of Death was used, and cancer of the prostate was defined as code C61. For each EPIC centre closure dates of the study period were defined as the latest dates of complete follow-up for both cancer incidence and vital status (dates varied between centres, from June 1999 to January 2003).

Case patients were men who developed prostate cancer after the date of blood collection and before the end of the study period, defined for each study centre by the latest date of follow-up. The cases with no available blood sample and those participants who had missing information on the date of the blood donation, or who had a history of another cancer (except non-melanoma skin cancer) at the time of the blood collection, were excluded. After these exclusions, laboratory measures for the current analysis were available for 950 cases: 288 cases in Denmark, 201 in Germany, 9 in Greece, 62 in Italy, 25 in the Netherlands, 93 in Spain, 94 in Sweden and 178 in the United Kingdom.

Data on the stage and grade of disease at diagnosis were collected from each centre, where possible. A total of 675 cases (71.1\%) had information on tumour stage; of these $475(50.0 \%)$ were classified as localised (tumour $(\mathrm{T})$-node $(\mathrm{N})$-metastasis $(\mathrm{M})$ categories $\mathrm{T} 0$ or $\mathrm{T} 1$ or $\mathrm{T} 2$ and $\mathrm{N} 0$ or NX and M0, or stage coded in recruitment centre as localised), and $200(21.1 \%)$ were classified as advanced (T3 or $\mathrm{T} 4, \mathrm{~N} 1+, \mathrm{M} 1$, or some combination of these, or stage coded in recruitment centre as metastatic). Information on histological grade was available for 720 cases (75.8\%); of these, 441 $(46.4 \%)$ were classified as low-grade (Gleason sum $<7$ or equivalent, i.e. coded as moderately or as well differentiated) and $279(29.4 \%)$ were classified as high-grade (Gleason sum $\geqslant 7$ or equivalent, i.e. coded as poorly differentiated or as undifferentiated).

Each case patient was matched to one control participant, with the exception of cases from Umeå, an EPIC-associated cohort in which case patients were matched to two control participants, selected at random among appropriate risk sets consisting of all male cohort members alive and free of cancer (except nonmelanoma skin cancer) at the time of diagnosis of the index case. An incidence density sampling protocol for control selection was used, such that controls could include participants who became a case later in time, whereas each control participant could also be sampled more than once. Matching criteria included: recruitment centre, age at enrolment ( \pm 6 months), time of day of blood collection $( \pm 1 \mathrm{~h})$, follow-up time (as close as possible), time between blood draw and last consumption of food or drinks $(<3$, $3-6,>6 h)$.

\section{Laboratory assays}

Plasma samples were analysed for three isoflavones (genistein, daidzein and equol) and two lignans (enterolactone and enterodiol) using ultra performance liquid chromatography-tandem mass spectrometry in the HFL laboratory, Fordham, UK using an adaptation of an earlier published method (Grace et al, 2007). The laboratory personnel who conducted the assays were blinded to the case or control status of the participants. Plasma samples from each case-control set were assayed within the same batch and analysed on the same day. Three quality control plasma samples were inserted into each assay batch and analysed in duplicate.

The quality control samples contained concentrations of genistein, daidzein, equol, enterolactone and enterodiol, which reflected low, medium and high ranges of the calibration chart $\left(0.1-500 \mathrm{ng} \mathrm{ml}^{-1}\right.$, e.g. equivalent to $0.37-1850 \mathrm{nmoll}^{-1}$ of genistein). The average intra-assay co-efficient of variation $(\mathrm{CV})$ ranged from 3.1 (enterolactone) to $5.9 \%$ (equol). The average inter-assay CVs ranged from 4.1 (enterodiol) to $6.2 \%$ (equol).

The lower limit of quantification, equivalent to the lowest point in the calibration curve, was $0.1 \mathrm{ng} \mathrm{ml}^{-1}$ for each analyte (equivalent to $0.37 \mathrm{nmoll}^{-1}$ of genistein, $0.39 \mathrm{nmoll}^{-1}$ of daidzein, $0.41 \mathrm{nmoll}^{-1}$ of equol, $0.34 \mathrm{nmoll}^{-1}$ of enterolactone and $0.33 \mathrm{nmoll}^{-1}$ of enterodiol); the percentage of samples in which levels were not detectable was $16 \%$ for genistein, $13 \%$ for daidzein, $43 \%$ for equol, $2 \%$ for enterolactone and $16 \%$ for enterodiol. For individuals with levels below this limit, phyto-oestrogen concentrations were imputed at $0.05 \mathrm{ng} \mathrm{ml}^{-1}$ (equivalent to $\sim 0.2 \mathrm{nmoll}^{-1}$ ).

\section{Statistical analysis}

Statistical analyses were carried out with the Stata 9 statistical software package (StataCorp, 2005). All tests of statistical significance were two-sided, and $P$-values below 0.05 were considered significant.

Differences in baseline characteristics of cases and controls were compared using conditional logistic regression models for categorical variables or a weighted paired $t$-test for continuous variables, comparing the value for the case with the value in the matched control participant, or the mean of the values in controls when there were two matched controls in a set (Rosner, 1982).

Spearman's rank correlation coefficients were calculated to assess the correlations between plasma levels of phyto-oestrogens among control participants.

Conditional logistic regression models were applied to calculate the relative risks (RRs) (odds ratios) for prostate cancer in relation to fifths of genistein, daidzein, enterolactone and enterodiol concentrations, using cut points defined by the quintiles among control participants for all centres combined and using the lowest category as reference. For equol, given the high proportion of values below the lower limit of quantification and an interest in the 
comparison between non-producers and producers, the grouping was as follows: not detected (non-producers), and those with detectable levels of equol (producers) divided into fourths using cut points defined by the quartiles of equol concentration among control participants for all centres combined. Likelihood ratio tests were used to assess heterogeneity, and tests for linear trend were obtained using a continuous variable with values equal to the median concentration within each quintile of plasma phytooestrogen concentration.

To examine the effects of potential confounders (other than the matching criteria, controlled for by design), the analyses were repeated including additional variables in the logistic regression models. These variables were smoking (never, past and present), body mass index (BMI, $\mathrm{kg} \mathrm{m}^{-2}$; in fourths), physical activity (inactive, moderately inactive and active) (Friedenreich et al, 2007) (we combined the 'moderately active' and 'active' categories), alcohol intake $(<8,8-15,16-39, \geqslant 40 \mathrm{~g}$ per day), marital status (married/cohabiting or not married/ cohabiting) and education level (primary or none, secondary and degree level). For each of these variables a small proportion of values was unknown; these values were included in the analyses as a separate category.

Likelihood ratio $\chi^{2}$-tests were used to examine the heterogeneity of the associations of phyto-oestrogen concentrations with risk of prostate cancer categorised according to prostate tumour stage (localised or advanced), histologic grade (low grade or high grade) and time to diagnosis ( $<4$ years after blood collection, $\geqslant 4$ years after blood collection). Likelihood ratio $\chi^{2}$-tests were also used to examine the heterogeneity of the associations of phyto-oestrogen concentrations with prostate cancer risk for participants categorised by age at blood collection $(<60$ or $\geqslant 60$ years) and by country of recruitment (eight countries).

\section{RESULTS}

Nine hundred and fifty men diagnosed with prostate cancer from recruitment until the end of follow-up and 1042 matched participants without prostate cancer were included in the analyses. Their median age at blood collection was 60 years (range $=43-76$ years).

When the characteristics of case patients and control participants were compared, the groups did not differ appreciably in most respects, but there were some small differences (Table 1). Compared with control participants, case patients had a slightly lower mean weight (80.1 and $81.1 \mathrm{~kg}$, respectively) and lower mean BMI (26.6 and $26.8 \mathrm{~kg} \mathrm{~m}^{-2}$, respectively), were less likely to be current smokers (24.3 and $28.7 \%$, respectively), and were less likely to be physically active ( 43.7 and $49.3 \%$, respectively).

Prostate cancer diagnosis followed blood collection by a median of 4.2 years (range $<1-15.1$ years) and the median age at diagnosis was 65 years (range $47-82$ years).

Correlations between the plasma concentrations of the individual phyto-oestrogens among control participants were strongest between genistein and daidzein $(r=0.71, P<0.001)$ and between the lignans, enterolactone and enterodiol $(r=0.38, P<0.001)$. Genistein and daidzein were weakly correlated with the lignans $(r=0.08-0.19)$. Plasma concentrations of equol were not significantly correlated with the concentrations of any of the other analytes.

Table 2 shows median plasma concentrations of genistein, daidzein, equol, enterolactone and enterodiol, with 5th to 95th percentiles, in study controls, overall and in the eight countries participating in the study. There was substantial variation in the median concentrations between the countries, with participants in the United Kingdom and the Netherlands generally having the highest levels of isoflavones and participants in Denmark having the highest levels of lignans.
Table I Characteristics of prostate cancer patients and control participants

\begin{tabular}{|c|c|c|}
\hline Characteristic & $\begin{array}{c}\text { Cases } \\
(n=950)\end{array}$ & $\begin{array}{r}\text { Controls } \\
(n=1042)\end{array}$ \\
\hline $\begin{array}{l}\text { Mean age at blood collection (years) } \\
\text { Weight }(\mathrm{kg})^{\mathrm{a}} \\
\text { Height }(\mathrm{cm})^{\mathrm{a}} \\
\text { BMI }\left(\mathrm{kg} \mathrm{m}^{-2}\right)^{\mathrm{a}}\end{array}$ & $\begin{aligned} & 60.4(5.8) \\
& 80.1(11.2) \\
& 173.6(6.9) \\
& 26.6(3.4)\end{aligned}$ & $\begin{aligned} 60.1 & (5.8) \\
81.1 & (11.9) \\
173.8 & (6.8) \\
26.8 & (3.6)\end{aligned}$ \\
\hline $\begin{array}{l}\text { Smoking, \% (n) } \\
\text { Never } \\
\text { Former } \\
\text { Current }\end{array}$ & $\begin{array}{l}32.4(301) \\
43.3(402) \\
24.3(226)\end{array}$ & $\begin{array}{l}31.1(309) \\
40.2(400) \\
28.7(285)\end{array}$ \\
\hline $\begin{array}{l}\text { Alcohol consumption, } \%(n)^{a} \\
\quad<8 \text { g per day } \\
\text { 8- } 15 \text { g per day } \\
16-39 \text { g per day } \\
\geqslant 40 \text { g per day }\end{array}$ & $\begin{array}{l}34.8(322) \\
19.9(184) \\
26.2(243) \\
19.1(177)\end{array}$ & $\begin{array}{l}37.2(37 \mid) \\
20.7(207) \\
23.2(23 \mid) \\
18.9(189)\end{array}$ \\
\hline $\begin{array}{l}\text { Physical activity, \% }(n)^{\text {a }} \\
\text { Inactive } \\
\text { Moderately inactive } \\
\text { Active }\end{array}$ & $\begin{array}{l}21.5(192) \\
34.9(312) \\
43.7(391)\end{array}$ & $\begin{array}{l}19.0(179) \\
31.7(299) \\
49.3(464)\end{array}$ \\
\hline $\begin{array}{l}\text { Marital status, } \%(n)^{\mathrm{a}} \\
\text { Married or cohabiting } \\
\text { Not married or cohabiting }\end{array}$ & $\begin{array}{l}89.2(494) \\
10.8(60)\end{array}$ & $\begin{array}{l}88.2(559) \\
11.8(75)\end{array}$ \\
\hline $\begin{array}{l}\text { Educational attainment, \% }(n)^{\mathrm{a}} \\
\text { Primary or equivalent } \\
\text { Secondary } \\
\text { Degree }\end{array}$ & $\begin{array}{l}37.9(347) \\
35.8(328) \\
26.3(241)\end{array}$ & $\begin{array}{l}40.3(400) \\
37.3(370) \\
22.5(223)\end{array}$ \\
\hline $\begin{array}{l}\text { Cases only } \\
\text { Time to diagnosis (years), \% (n) } \\
\quad<2 \\
\quad 2-<4 \\
4-<6 \\
6-<8 \\
\geqslant 8\end{array}$ & $\begin{array}{l}18.3(174) \\
28.1(267) \\
30.1(286) \\
16.0(152) \\
7.5(71)\end{array}$ & - \\
\hline $\begin{array}{l}\text { Year of diagnosis, median (range) } \\
\text { Age at diagnosis } \\
\text { Stage, \% ( }(n)\end{array}$ & $\begin{array}{l}2000(1994-2005) \\
64.9(5.7)\end{array}$ & - \\
\hline $\begin{array}{l}\text { Localised } \\
\text { Advanced } \\
\text { Unknown }\end{array}$ & $\begin{array}{l}50.0(475) \\
21.1(200) \\
29.0(275)\end{array}$ & $\begin{array}{l}- \\
- \\
-\end{array}$ \\
\hline $\begin{array}{l}\text { Grade, } \%(n) \\
\text { Low grade } \\
\text { High grade } \\
\text { Unknown }\end{array}$ & $\begin{array}{l}46.4(441) \\
29.4(279) \\
24.1(230)\end{array}$ & $\begin{array}{l}- \\
-\end{array}$ \\
\hline
\end{tabular}

$\mathrm{BMI}=$ body mass index. Values are means (s.d.) except where indicated. ${ }^{a}$ Unknown for some participants; the calculations of percentages exclude missing values. ${ }^{\text {bTime }}$ between blood collection and diagnosis among case patients. ' $G$ leason score $<7$ or coded as well or moderately differentiated. ${ }^{\mathrm{d} G}$ Gleason score $\geqslant 7$ or coded as poorly differentiated or undifferentiated.

Table 3 shows the median plasma concentrations of genistein, daidzein, equol, enterolactone and enterodiol in case patients and control participants. The only weighted paired $t$-test of the differences between cases and controls that was statistically significant was for genistein (median concentrations 1.8 and $2.1 \mathrm{ng} \mathrm{ml}^{-1}$, respectively, $P=0.007$ ).

Table 4 shows the RRs for prostate cancer by plasma phytooestrogen concentration. There was a statistically significant inverse association between genistein and risk for prostate cancer; 
Table 2 Median (5-95 percentile) concentrations of phyto-oestrogens ${ }^{\mathrm{a}}$ among controls by country

\begin{tabular}{|c|c|c|c|c|c|c|c|c|c|}
\hline $\begin{array}{l}\text { Phyto-oestrogen } \\
\left(\mathrm{ng} \mathrm{ml}^{-1}\right)\end{array}$ & $\begin{array}{c}\text { Denmark } \\
n=\mathbf{2 8 8}\end{array}$ & $\begin{array}{c}\text { Germany } \\
n=201\end{array}$ & Greece $n=9$ & Italy $n=62$ & $\begin{array}{c}\text { The } \\
\text { Netherlands } \\
n=\mathbf{2 5}\end{array}$ & Spain $n=93$ & Sweden $n=186$ & $\begin{array}{l}\text { The United } \\
\text { Kingdom } \\
n=178\end{array}$ & Total $n=1042$ \\
\hline Genistein & $2.0(0.05-23.8)$ & $2.2(0.05-23.5)$ & $0.05(0.05-17.2)$ & $1.3(0.05-10.3)$ & $4.6(0.2-40.1)$ & $1.2(0.05-7.4)$ & I.I $(0.05-\mid 4.9)$ & $5.4(0.2-4 \mid .5)$ & $2.1(0.05-24.5)$ \\
\hline Daidzein & $1.4(0.05-12.8)$ & $1.0(0.05-13.9)$ & $0.3(0.05-0.9)$ & $0.3(0.05-16.2)$ & $2.7(0.5-25.0)$ & $0.5(0.05-2.4)$ & $0.6(0.05-7.8)$ & $3.6(0.2-20.2)$ & $1.1(0.05-13.9)$ \\
\hline Equol & $0.1(0.05-0.9)$ & $0.05(0.05-0.7)$ & $0.05(0.05-0.6)$ & $0.05(0.05-1.7)$ & $0.05(0.05-0.5)$ & $0.1(0.05-0.7)$ & $0.5(0.05-1.4)$ & $0.15(0.05-0.8)$ & $0.1(0.05-1.0)$ \\
\hline Enterolactone & $5.5(0.6-28.1)$ & $3.6(0.3-15.1)$ & $2.0(0.9-40.1)$ & $2.7(0.1-17.0)$ & $3.8(0.05-23.0)$ & $2.2(0.2-8.2)$ & $3.6(0.7-16.2)$ & $3.7(0.5-21.0)$ & $3.7(0.4-20.4)$ \\
\hline Enterodiol & $0.4(0.05-6.6)$ & $0.3(0.05-3.5)$ & $0.1(0.05-0.8)$ & $0.4(0.05-2.9)$ & $0.1(0.05-3.7)$ & $0.1(0.05-1.3)$ & $0.2(0.05-1.6)$ & $0.3(0.05-2.1)$ & $0.3(0.05-2.9)$ \\
\hline
\end{tabular}

aFor participants with undetected phyto-oestrogens levels, data were imputed at $0.05 \mathrm{ng} \mathrm{ml}^{-1}$, half the lower limit of detection.

Table 3 Median plasma phyto-oestrogen concentrations (5-95 percentile) among prostate cancer case patients and control participants ${ }^{\mathrm{a}}$

\begin{tabular}{|c|c|c|c|c|c|}
\hline \multirow[b]{2}{*}{ Phyto-oestrogen } & \multirow{2}{*}{$\begin{array}{l}\text { Number of } \\
\text { cases/controls }\end{array}$} & \multirow[b]{2}{*}{ Not detected ${ }^{\mathbf{b}}, \mathbf{n}(\%)$} & \multicolumn{2}{|c|}{ Median concentration (5-95 percentile), $\mathrm{ng} \mathrm{ml}^{-1}$} & \multirow[b]{2}{*}{$P$ for difference } \\
\hline & & & Case patients & Control participants & \\
\hline Genistein & $950 / 1042$ & $317(15.9)$ & $1.8(0.05-22.3)$ & $2.1(0.05-24.5)$ & 0.007 \\
\hline Daidzein & $950 / 1042$ & $250(12.6)$ & $1.1(0.05-11.6)$ & $1.1(0.05-13.9)$ & 0.114 \\
\hline Equol & $950 / 1042$ & $855(42.9)$ & $0.2(0.05-1.0)$ & $0.1(0.05-1.0)$ & 0.119 \\
\hline Enterolactone & $950 / 1042$ & $34(1.7)$ & $3.8(0.2-19.5)$ & $3.7(0.4-20.4)$ & 0.473 \\
\hline
\end{tabular}

${ }^{a}$ Case patients and control participants were matched on recruitment centre, age at enrolment ( \pm 6 months), time of day of blood collection ( \pm I h), follow-up time (as close as possible), time between blood draw and last consumption of food or drinks ( $<3,3-6,>6 \mathrm{~h})$. ${ }^{\mathrm{b}}$ Not detected; data for these participants were imputed at $0.05 \mathrm{ng} \mathrm{ml}^{-1}$, half the lower limit of detection. 'Two-sided P-values; weighted paired $t$-test, using the mean value in controls for each case-control set with more than one control.

compared with the men in the lowest fifth of genistein concentration, men in the highest fifth had a RR of disease of $0.71(95 \%$ confidence interval $(\mathrm{CI}) 0.53,0.96 ; P$ linear trend $=0.032$ ). When the analysis was repeated, additionally adjusting for smoking, BMI, physical activity, alcohol intake, marital status and education level, this association was borderline statistically significant (RR: 0.74 , $95 \%$ CI $0.54,1.00 ; P$ linear trend $=0.051)$. We observed no statistically significant association between risk for prostate cancer and the concentrations of daidzein, equol, enterolactone or enterodiol, with or without adjustment for potential confounders. There was no statistical evidence of heterogeneity in the trends in risk for prostate cancer according to the age of the men at blood collection, nor by country of recruitment. Neither there was statistical evidence of heterogeneity in the associations of phytooestrogen concentrations with risk of prostate cancer categorised according to prostate tumour stage, histological grade or time to diagnosis (data not shown).

\section{DISCUSSION}

In this first large prospective study, higher plasma concentrations of genistein were associated with a lower risk of prostate cancer. Risk for prostate cancer did not vary significantly by plasma concentration of daidzein or equol or by plasma concentrations of the lignans, enterolactone and enterodiol.

The design of this study offers several methodological advantages. The direct measurement of phyto-oestrogen concentrations in the circulation makes it possible to capture phyto-oestrogen exposure from all sources, including those that may be inadequately represented in food composition databases. For example, although the most abundant sources of isoflavones in the diet are soy foods, such as tofu and soymilk, the intake of which is low but variable across the European countries in EPIC (Keinan-Boker et al, 2002), soy additives are now also found in an increasing range of processed foods (Liggins et al, 2002). Isoflavones are also present in certain other vegetables, fruits and nuts (Liggins et al, $2000 \mathrm{a}, \mathrm{b})$, although in much lower concentrations than in soy foods. We were also able to assess exposure to specific phytooestrogens, which is particularly important as individual phytooestrogens have been found to differ in their biological activity, (Magee and Rowland, 2004) and the phyto-oestrogens absorbed through the intestine are dependent not only on dietary intake of phyto-oestrogens and their precursors, but also on the activity of intestinal bacteria that metabolise phyto-oestrogens (Rowland et al, 2003). Further strengths of this study include the large sample size and the varied dietary habits of the study population, linked with variation in plasma phyto-oestrogens levels across the different countries participating in the study (Peeters et al, 2007).

Our findings for plasma genistein are consistent with the findings from one small prospective study on circulating concentrations of isoflavones and prostate cancer, which found a non-significant dose-dependent reduction in risk in relation to concentrations of genistein among 40 men with prostate cancer and 101 without prostate cancer from the Japanese Collaborative Cohort Study (Ozasa et al, 2004). The only other published studies we are aware of are the EPIC-Norfolk analyses of a total of 193 men with prostate cancer, 141 of whom are included in this study (Low et al, 2006; Ward et al, 2008), in which no associations were found between serum levels of phyto-oestrogens and risk of prostate cancer.

Findings from the Japanese study (Ozasa et al, 2004) also suggested a modest and non-significant reduction in risk in relation to daidzein, which is consistent with the non-significant reduction in this study. This possible relationship may be a consequence of the association between genistein and risk, given the close correlation between circulating concentrations of these isoflavones. The findings from this study for equol, a metabolite of daidzein formed by microflora in the intestine, are in accordance with data from the Japanese study, which suggested no significant association (Ozasa et al, 2004). However, we have limited power in this study to assess the relationship among our study participants, as a high proportion of participants had negligible circulating 
Relative risk ${ }^{\mathrm{a}}$ for prostate cancer by fifth of plasma phyto-oestrogen concentration

Fifth of phyto-oestrogen

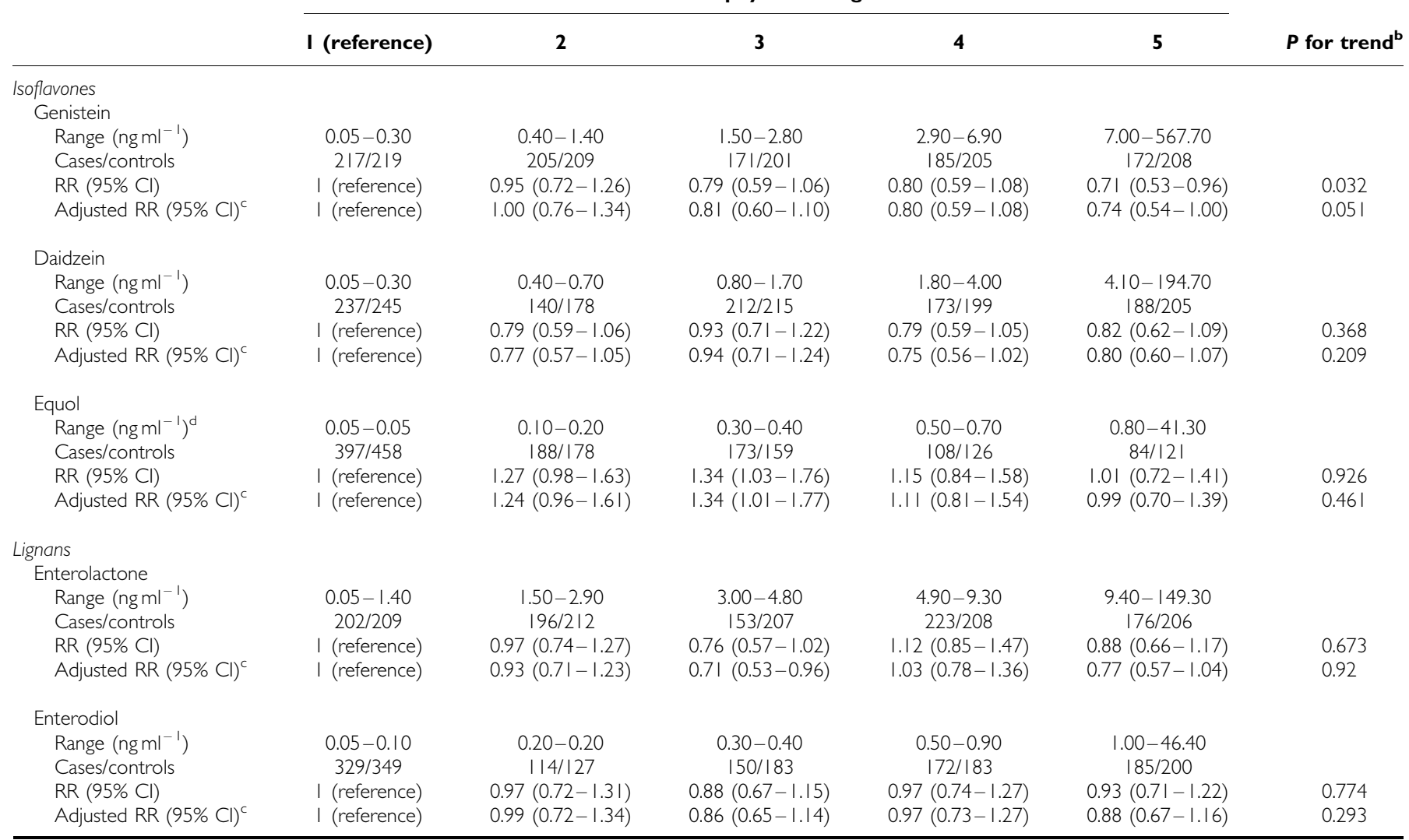

$\mathrm{BMI}=$ body mass index; $\mathrm{Cl}=$ confidence interval; $\mathrm{RR}=$ relative risk. ${ }^{\mathrm{a} C}$ Case patients and control participants were matched on recruitment centre, age at enrolment $( \pm 6$ months), time of day of blood collection $( \pm \mid \mathrm{h})$, follow-up time (as close as possible), time between blood draw and last consumption of food or drinks $(<3,3-6,>6 \mathrm{~h})$. ${ }^{\mathrm{b}} \mathrm{Test}$ for trend obtained by replacing the categorical variable with a continuous variable equal to the median concentration within each fifth of plasma phyto-oestrogen concentration. 'Adjustment was made for smoking (never, past and present), physical activity (inactive, moderately inactive and active), alcohol intake $(<8,8-15,16-39, \geqslant 40 \mathrm{~g}$ per day), marital status (married or cohabiting, not married or cohabiting), education (primary or none, secondary and degree level) and BMI (fourths). ${ }^{\mathrm{d} F o r}$ equol, given the high proportion of values below the lower limit of detection and the interest in the comparison between non-producers and producers of equol, the grouping was as follows: not detected (non-producers) and those with detectable levels of equol (producers) divided into four groups using the following cut-points, $0.30,0.50$ and $0.80 \mathrm{ng} \mathrm{ml}^{-1}$.

levels of equol, probably reflecting the fact that exposure to equol is dependent on both the consumption of daidzein and on being an 'equol-producer'; $30-50 \%$ of individuals do not excrete equol when challenged daily with soy foods (Setchell et al, 2002).

The findings from this study do not support the hypothesis that circulating lignans play a major role in the pathogenesis of prostate cancer, and are in agreement with results from the five earlier published prospective studies of circulating concentrations of enterolactone in relation to risk for prostate cancer (Stattin et al, 2002, 2004; Kilkkinen et al, 2003; Low et al, 2006; Ward et al, 2008).

Our finding of a possible protective association of genistein with prostate cancer risk is consistent with the experimental data from in vivo and in vitro studies (Bingham et al, 1998; Bylund et al, 2000; Goetzel et al, 2007). This association may be mediated by oestrogenic and/or a number of anti-carcinogenic properties, although the biological effects of exposure to phyto-oestrogens in humans remain uncertain (Bingham et al, 1998; Magee and Rowland, 2004; McCann et al, 2005; McCormick et al, 2007). Phyto-oestrogens have a structure similar to mammalian oestrogens and can bind to the oestrogen receptor (Morito et al, 2001; Mueller et al, 2004). Experimental evidence suggests that the interaction of isoflavones with the oestrogen receptor beta (ER- $\beta$ ) might be particularly important in the development of prostate cancer (Morito et al, 2001; McCarty, 2006); compared with daidzein, genistein has a much greater affinity for the ER- $\beta$, selectively promoting ER- $\beta$ signalling which in turn may suppress cellular proliferation and promote differentiation in the prostate (McCarty, 2006; Ricke et al, 2007). It is unclear though whether the levels of dietary phyto-oestrogen exposure in humans are sufficiently high to exert a biological effect (Liggins et al, 2000b; McCarty, 2006). The median circulating genistein concentration in the top fifth of the distribution in this study, $14 \mathrm{ng} \mathrm{ml}^{-1}$, is approximately seven times lower than the average concentration of $87 \mathrm{ng} \mathrm{ml}^{-1}$ for cases and $99 \mathrm{ng} \mathrm{ml}^{-1}$ for controls found in the study of Japanese men (Ozasa et al, 2004). However, despite these lower levels of phyto-oestrogens we found some evidence of an association with prostate cancer risk.

We found no strong evidence for heterogeneity in the relationship of plasma phyto-oestrogens with prostate cancer risk by age at blood collection. These findings are consistent with an earlier study, which found no significant associations after stratifying by age (Stattin et al, 2004).

In this study, we were able to evaluate whether risk for prostate cancer in relation to circulating phyto-oestrogen concentrations varied by tumour characteristic. We found no evidence for a difference in the relationship between plasma phyto-oestrogens 
and prostate cancer risk by stage or histological grade of the disease. These results are consistent with the findings from two other studies, which also reported no association of circulating enterolactone concentrations with localised or with advanced stage disease (Stattin et al, 2002, 2004; Kilkkinen et al, 2003). To our knowledge, no earlier published prospective studies have reported results for prediagnostic concentrations of circulating isoflavones in relation to prostate cancer risk stratified by tumour characteristics. The conclusions that can be drawn from this study, however, are limited by the small numbers in each category of tumour characteristic, as shown by the width of the CIs.

The findings from this large prospective study in European men suggest that higher concentrations of circulating genistein are associated with a lower risk for prostate cancer. No evidence was found for a protective association with plasma lignans. Further large prospective analyses, and ultimately pooled analyses, are needed to confirm this apparent association with genistein concentration and to examine associations between the circulating phyto-oestrogen concentrations and prostate cancer subtypes. Given that the only established risk factors for the disease (age, family history and ethnicity) are not amenable to modification, the possible protective effect of genistein could offer an opportunity for the development of a preventative intervention.

\section{ACKNOWLEDGEMENTS}

We thank the participants in the EPIC study, Carine Beissy and Bertrand Hémon at IARC and Laure Dossus at DKFZ for their expertise in data handling, and Philip Grace at HFL for laboratory analyses. This study was sponsored by grants from Cancer Research UK; European Commission: Public Health and Consumer Protection Directorate 1993-2004; Research Directorate-General 2005; German Cancer Aid; German Cancer Research Center; German Federal Ministry of Education and Research; Danish Cancer Society; Health Research Fund (FIS) of the Spanish Ministry of Health; ISCIII Red de Centros RCESP C03/09, Spain; Spanish Regional Governments of Andalusia, Asturia, Basque country, Murcia, and Navarra; Medical Research Council, UK; the Stroke Association, UK; British Heart Foundation; Department of Health, UK; Food Standards Agency, UK; the Wellcome Trust, UK; Greek Ministry of Health; Greek Ministry of Education; Italian Association for Research on Cancer (AIRC); Dutch Ministry of Public Health, Welfare and Sports; Dutch Ministry of Health; Dutch Prevention Funds; LK Research Funds; Dutch ZON (Zorg Onderzoek Nederland). The sponsors had no role in the study design, data collection, analysis, interpretation of results or writing of the paper.

\section{REFERENCES}

Allen NE, Sauvaget C, Roddam AW, Appleby P, Nagano J, Suzuki G, Key TJ, Koyama K (2004) A prospective study of diet and prostate cancer in Japanese men. Cancer Causes Control 15: $911-920$

Bingham SA, Atkinson C, Liggins J, Bluck L, Coward A (1998) Phytooestrogens: where are we now? Br J Nutr 79: 393-406

Bylund A, Zhang J-X, Bergh A, Damber JE, Widmark A, Johansson A, Adlercreutz H, Aman P, Shepherd MJ, Hallmans G (2000) Rye bran and soy protein delay growth and increase apoptosis of human LNCaP prostate adenocarcinoma in nude mice. Prostate 42: 304-314

Friedenreich C, Cust A, Lahmann PH, Steindorf K, Boutron-Ruault MC, Clavel-Chapelon F, Mesrine S, Linseisen J, Rohrmann S, Pischon T, Schulz M, Tjonneland A, Johnsen NF, Overvad K, Mendez M, Arguelles MV, Garcia CM, Larranaga N, Chirlaque MD, Ardanaz E, Bingham S, Khaw KT, Allen N, Key T, Trichopoulou A, Dilis V, Trichopoulos D, Pala V, Palli D, Tumino R, Panico S, Vineis P, Bueno-de-Mesquita HB, Peeters PH, Monninkhof E, Berglund G, Manjer J, Slimani N, Ferrari P, Kaaks R, Riboli E (2007) Physical activity and risk of endometrial cancer: the European prospective investigation into cancer and nutrition. Int $J$ Cancer 121: $347-355$

Goetzel MA, Van Veldhuizen PJ, Thrasher JB (2007) Effects of soy phyto-oestrogens on the prostate. Prostate Cancer Prostatic Dis 10: $216-223$

Grace PB, Mistry NS, Carter MH, Leathem AJ, Teale P (2007) High throughput quantification of phyto-oestrogens in human urine and serum using liquid chromatography/tandem mass spectrometry (LC-MS/ MS). J Chromatogr B Analyt Technol Biomed Life Sci 853: 138-146

Jacobsen BK, Knutsen SF, Fraser GE (1998) Does high soy milk intake reduce prostate cancer incidence? The Adventist Health Study (United States). Cancer Causes Control 9: 553-557

Keinan-Boker L, Peeters PH, Mulligan AA, Navarro C, Slimani N, Mattisson I, Lundin E, McTaggart A, Allen NE, Overvad K, Tjønneland A, ClavelChapelon F, Linseisen J, Haftenberger M, Lagiou P, Kalapothaki V, Evangelista A, Frasca G, Bueno-de-Mesquita HB, van der Schouw YT, Engeset D, Skeie G, Tormo MJ, Ardanaz E, Charrondière UR, Riboli E (2002) Soy product consumption in 10 European countries: the European Prospective Investigation into Cancer and Nutrition (EPIC) study. Public Health Nutr 5: $1217-1226$

Kilkkinen A, Virtamo J, Virtanen MJ, Adlercreutz H, Albanes D, Pietinen P (2003) Serum enterolactone concentration is not associated with prostate cancer risk in a nested case-control study. Cancer Epidemiol Biomarkers Prev 12: $1209-1212$

Kurahashi N, Iwasaki M, Sasazuki S, Otani T, Inoue M, Tsugane S (2007) Soy product and isoflavone consumption in relation to prostate cancer in Japanese men. Cancer Epidemiol Biomarkers Prev 16: 538-545
Liggins J, Bluck LJ, Runswick S, Atkinson C, Coward WA, Bingham SA (2000a) Daidzein and genistein contents of vegetables. Br J Nutr 84: 717-725

Liggins J, Bluck LJ, Runswick S, Atkinson C, Coward WA, Bingham SA (2000b) Daidzein and genistein content of fruits and nuts. J Nutr Biochem 11: $326-331$

Liggins J, Mulligan A, Runswick S, Bingham SA (2002) Daidzein and genistein content of cereals. Eur J Clin Nutr 56: $961-966$

Low YL, Taylor JI, Grace PB, Mulligan AA, Welch AA, Scollen S, Dunning AM, Luben RN, Khaw KT, Day NE, Wareham NJ, Bingham SA (2006) Phyto-oestrogen exposure, polymorphisms in COMT, CYP19, ESR1, and SHBG genes, and their associations with prostate cancer risk. Nutr Cancer 56: $31-39$

Magee PJ, Rowland IR (2004) Phyto-oestrogens, their mechanism of action: current evidence for a role in breast and prostate cancer. Br J Nutr 91: $513-531$

McCann MJ, Gill CI, McGlynn H, Rowland IR (2005) Role of mammalian lignans in the prevention and treatment of prostate cancer. Nutr Cancer 52: $1-14$

McCarty MF (2006) Isoflavones made simple - genistein's agonist activity for the beta-type estrogen receptor mediates their health benefits. Med Hypotheses 66: $1093-1114$

McCormick DL, Johnson WD, Bosland MC, Lubet RA, Steele VE (2007) Chemoprevention of rat prostate carcinogenesis by soy isoflavones and by Bowman-Birk inhibitor. Nutr Cancer 57: 184-193

Morito K, Hirose T, Kinjo J, Hirakawa T, Okawa M, Nohara T, Ogawa S, Inoue S, Muramatsu M, Masamune Y (2001) Interaction of phytooestrogens with estrogen receptors alpha and beta. Biol Pharm Bull 24: $351-356$

Mueller SO, Simon S, Chae K, Metzler M, Korach KS (2004) Phytooestrogens and their human metabolites show distinct agonistic and antagonistic properties on estrogen receptor alpha (ERalpha) and ERbeta in human cells. Toxicol Sci 80: $14-25$

Nomura AM, Hankin JH, Lee J, Stemmermann GN (2004) Cohort study of tofu intake and prostate cancer: no apparent association. Cancer Epidemiol Biomarkers Prev 13: $2277-2279$

Ozasa K, Nakao M, Watanabe Y, Hayashi K, Miki T, Mikami K, Mori M, Sakauchi F, Washio M, Ito Y, Suzuki K, Wakai K, Tamakoshi A (2004) Serum phyto-oestrogens and prostate cancer risk in a nested case-control study among Japanese men. Cancer Sci 95: 65-71

Perabo FGE, Von Low EC, Ellinger J, von Rucker A, Muller SC, Bastian PJ (2008) Soy isoflavone genistein in prevention and treatment of prostate cancer. Prostate Cancer Prostatic Dis 11: 6-12

Peeters PH, Slimani N, van der Schouw YT, Grace PB, Navarro C, Tjonneland A, Olsen A, Clavel-Chapelon F, Touillaud M, Boutron-Ruault 
MC, Jenab M, Kaaks R, Linseisen J, Trichopoulou A, Trichopoulos D, Dilis V, Boeing H, Weikert C, Overvad K, Pala V, Palli D, Panico S, Tumino R, Vineis P, Bueno-de-Mesquita HB, van Gils CH, Skeie G, Jakszyn P, Hallmans G, Berglund G, Key TJ, Travis R, Riboli E, Bingham SA (2007) Variations in plasma phyto-oestrogen concentrations in European adults. J Nutr 137: $1294-1300$

Riboli E, Hunt KJ, Slimani N, Ferrari P, Norat T, Fahey M, Charrondière UR, Hémon B, Casagrande C, Vignat J, Overvad K, Tjønneland A, Clavel-Chapelon F, Thiébaut A, Wahrendorf J, Boeing H, Trichopoulos D, Trichopoulou A, Vineis P, Palli D, Bueno-De-Mesquita HB, Peeters PH, Lund E, Engeset D, González CA, Barricarte A, Berglund G, Hallmans G, Day NE, Key TJ, Kaaks R, Saracci R (2002) European Prospective Investigation into Cancer and Nutrition (EPIC): study populations and data collection. Public Health Nutr 5: 1113-1124

Ricke WA, Wang Y, Cunha GR (2007) Steroid hormones and carcinogenesis of the prostate: the role of estrogens. Differentiation 75: $871-882$

Rosner B (1982) A generalization of the paired t-test. Appl Stat 31: 9-13

Rowland I, Faughnan M, Hoey L, Wahala K, Williamson G, Cassidy A (2003) Bioavailability of phyto-oestrogens. Br J Nutr 89: S45-S58

Setchell KD, Brown NM, Lydeking-Olsen E (2002) The clinical importance of the metabolite equol-a clue to the effectiveness of soy and its isoflavones. J Nutr 132: $3577-3584$
Severson RK, Nomura AM, Grove JS, Stemmermann GN (1989) A prospective study of demographics, diet, and prostate cancer among men of Japanese ancestry in Hawaii. Cancer Res 49: 1857-1860

StataCorp (2005) Stata Statistical Software: Release 9. StataCorp LP: College Station, TX

Stattin P, Adlercreutz H, Tenkanen L, Jellum E, Lumme S, Hallmans G, Harvei S, Teppo L, Stumpf K, Luostarinen T, Lehtinen M, Dillner J, Hakama M (2002) Circulating enterolactone and prostate cancer risk: a Nordic nested case-control study. Int J Cancer 99: 124-129

Stattin P, Bylund A, Biessy C, Kaaks R, Hallmans G, Adlercreutz H (2004) Prospective study of plasma enterolactone and prostate cancer risk (Sweden). Cancer Causes Control 15: 1095-1102

Ward H, Chapelais G, Kuhnle GGC, Luben R, Khaw KT, Bingham S (2008) Lack of prospective associations between plasma and urinary phytoestrogens and risk of prostate or colorectal cancer in the European Prospective Investigation into Cancer-Norfolk Study. Cancer Epidemiol Biomarkers Prev 17: 2891-2893

cc)(-) $\Theta$ This work is licensed under the Creative Commons BY NG ND Attribution-NonCommercial-NoDerivs 3.0 License. To view a copy of this license, visit http://creativecommons.org/ licenses/by-nc-nd/3.0/. 